msh-mss Mathématiques et sciences humaines

136 | Hiver 1996

Varia

\title{
Un dictionnaire électronique évolutif par apprentissage
}

An electric dictionary with a learning system

Brigitte Le Pevedic et Denis Maurel

\section{CpenEdition}

1 Journals

Édition électronique

URL : http://journals.openedition.org/msh/2700

DOI : $10.4000 / \mathrm{msh} .2700$

ISSN : 1950-6821

Éditeur

Centre d'analyse et de mathématique sociales de l'EHESS

Édition imprimée

Date de publication : 1 décembre 1996

ISSN : 0987-6936

Référence électronique

Brigitte Le Pevedic et Denis Maurel, « Un dictionnaire électronique évolutif par apprentissage », Mathématiques et sciences humaines [En ligne], 136 | Hiver 1996, mis en ligne le 10 février 2006, consulté le 23 juillet 2020. URL : http://journals.openedition.org/msh/2700 ; DOI : https://doi.org/ $10.4000 / m s h .2700$

Ce document a été généré automatiquement le 23 juillet 2020.

(c) École des hautes études en sciences sociales 


\section{Un dictionnaire électronique évolutif par apprentissage}

An electric dictionary with a learning system

Brigitte Le Pevedic et Denis Maurel

\section{RÉSUMÉS}

Dans le cadre du développement d'un système d'aide à la saisie rapide de textes pour des personnes handicapées physiques, nous allons aborder, dans cet article, l'approche lexicale. Le principe du système est le suivant : en fonction du début du texte déjà saisi et des premières lettres du mot en cours de saisie nous comptons proposer à l'usager la liste des mots les plus fréquents dans la ou les catégories grammaticales les plus probables, tout en respectant le cadre sémantique. Il s'agit donc de réaliser un dictionnaire électronique comportant des indications morphologiques, syntaxiques et sémantiques, ainsi qu'un système d'apprentissage permettant une adaptation de ce dictionnaire à l'utilisateur.

This paper presents the work to construct a communication-aid software in order to speed up the capture of data for physically handicapped people. In this article, the lexical approach is developed. The principle is : in function for beginning texts and the first letters of words current capture, we want to suggest to users a list of more frequently used words in a more probable grammatical category with a correct semantical context. We propose therefore to carry out an electronic dictionary with morphological, syntactical and semantical informations and a learning system which allows adjustment to this dictionary for the user. 
INDEX

Thèmes : cognitives (sciences), linguistique, sémantique 